\title{
Production of Lipase and Phospholipase Enzymes from Pseudomonas sp. and Their Action on Phospholipids
}

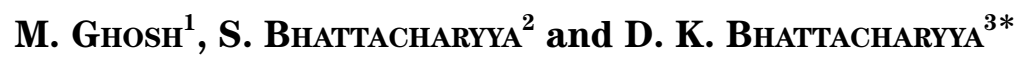 \\ ${ }^{I}$ Presently working at Ceramic Membrane Section, Central Glass \& Ceramic Research Institute \\ (196, Raja S.C.Mullick Road,Kolkata - 700032, INDIA) \\ ${ }^{2}$ Presently working at Dept. of Chemistry, Narula Institute of Technology \\ (Agarpara, West Bengal, INDIA) \\ ${ }^{3}$ Department of Chemical Technology (Oil Technology Division) University of Calcutta \\ (92, Acharyya Prafulla Chandra Roy Road, Kolkata - 700 009, INDIA)
}

Edited by T. Itoh, Kitasato Univ., and accepted February 18, 2005 (received for review November 4, 2004)

\begin{abstract}
One bacterial strain was isolated from soyphospholipid enriched media of pseudomonas group and cultured in peptone, yeast extract and beef extract containing media. The kinds of enzyme from the bacteria appeared to have both lipase and phospholipase activity and specificity as evident from their mode of action on triacylglyceride and phospholipid as well.

Key words: Pseudomonas, lipase, phospholipase
\end{abstract}

Lipolytic enzymes have an increasing use in the food and detergent industries and recently their role in producing various structured and/or modified lipids has been emphasized $(1,2)$. Lipases are enzymes that hydrolyse both triacylglycerides and phospholipids (3), while phospholipases only hydrolyse phospholipids (4). A great deal of work has been carried out for the isolation of both kinds of lipases from various sources particularly from microbial sources (5-10). Various report show that phospholipases are produced from animals, plants and microorganisms and a number of phospholipases of different kinds have been purified and characterized from Pseudomonas sp. $(11,12)$. Other report shows that it can utilize peptone and yeast as nitrogen sources (13).

This report presents a preliminary investigation on the kinds of lipases produced from the Pseudomonas putida SB 3 obtained from soil enriched with soyphospholipid.

All solvents used were of AR grade and purchased from E-MERCK India Ltd., Mumbai, India. Refined Soybean oil with no acetone insoluble was obtained at laboratory by successive extraction with acetone of commercial oil collected from local market (Kolkata, India) and finally storing the oil at $5{ }^{\circ} \mathrm{C}$ for 10 days and filtered through a Buckner filter. Purity of the samples was tested by TLC analysis. Soyphospholipid was extracted from crude soybean oil by water degumming method and was purified by repeated Chloroformmethanol extraction.

Soil samples were collected from crop fields and gardens. There were altogether 15 samples of soil of which 10 were selected for the experiment on modification of soyphospholipid by enrichment test (14).

Morphological and physiological characterization of isolates was examined at different time for Gram reaction and cell morphology (identification was done at National Institute of Cholera and Enteric Diseases, Kolkata). Other biochemical tests were performed following directions of the latest edition of Bergey's man-

\footnotetext{
*Correspondence to: D.K. Bhattacharyya, Department of Chemical Technology (Oil Technology Division), University of Calcutta, 92, Acharyya Prafulla Chandra Roy Road, Kolkata - 700 009, INDIA

E-mail: dkb_oiltech@yahoo.co.in
} 
ual (15).

Cultures were incubated in the sterilized nutrient media (consisting of $1 \mathrm{~g}$ beef extract, $2 \mathrm{~g}$ yeast extract, $5 \mathrm{~g}$ peptone, and $0.5 \mathrm{~g}$ sodium chloride in $1000 \mathrm{~mL}$ of distilled water) with shaking at $37^{\circ} \mathrm{C}$ for $3-15$ days. The $\mathrm{pH}$ of the medium was kept nearly at 7.0. To the resulting culture broth $0.1 \%(\mathrm{w} / \mathrm{v})$ of deoiled phospholipid was added as substrate and incubated at $37^{\circ} \mathrm{C}$ under continuous shaking. Samples from the cultures as well as from sterile controls were collected and analyzed by thin layer chromatography.

The hydrolytic activity of enzymes was determined by cupric-acetate method (16). To monitor the enzyme reaction, $1 \mathrm{~mL}$ of the culture supernatant was taken in a screw capped test tube, which was solubilized in $1 \mathrm{~mL}$ of standard phosphate buffer, $\mathrm{pH}$ 7.0, followed by the addition of four drops groundnut oil (GNO). The testtube was then shaken vigorously at 162 strokes/min in a shaker at $37^{\circ} \mathrm{C}$ for $30 \mathrm{~min}$. At the end of the reaction, $6(\mathrm{~N}) \mathrm{HCl}$ and $5 \mathrm{~mL}$ of isooctane was added to stop the reaction and to extract the free fatty acids (FFA). Then $1 \mathrm{~mL}$ of clear isooctane in the upper layer was carefully drawn into a test-tube and its free fatty acid content was determined from the standard curve by the above method ( $1 \mathrm{U}$ of enzyme activity $=\mu \mathrm{mol}$ of FFA produced $/ \mathrm{min}$.)

Of all the bacteria isolates, a particular gram negative, rod shaped strain, SB 3 was found to produce the enzyme to a considerable extent.

Preparation of the acetone powdered form of the lipase \& phospholipase was done by taking $60 \mathrm{~mL}$ of the culture medium $(72 \mathrm{~h})$ mixed with $60 \mathrm{~mL}$ acetone and keeping it for $1 \mathrm{~h}$ at $0^{\circ} \mathrm{C}$ in a refrigerator. This was then centrifuged in a cold centrifuge at $4^{\circ} \mathrm{C}$ at $15,000 \mathrm{~g}$ for $20 \mathrm{~min}$. The clear liquid at the top was decanted and the whole residual mass was dried in a vacuum at $40^{\circ} \mathrm{C}$ for $1 \mathrm{~h}$. The powder form of enzyme was stored at $-30^{\circ} \mathrm{C}$.

Esterification activity of enzymes was measured (17) with butyric acid $(0.16 \mathrm{~mol})$ and butanol $(0.33 \mathrm{~mol})$ in n-heptane. The experiment with each lipase was set up with $50 \mathrm{~mL}$ stoppered conical flask containing $3 \mathrm{~mL}$ of stock solution with the appropriate quantity of the lipase. Butanol did not react with butyric acid in the absence of the lipase within $2 \mathrm{~h}$ employed for measuring the activity.

Assay of phospholipase enzymes was done by the action of isolated enzymes on phospholipid. As phos- pholipids can be hydrolysed by both lipase and phospholipase enzymes and to ascertain therefore the phospholipase activity in the enzyme mixture, the detail analysis of the hydrolysed product should be determined. The deoiled phospholipid (about $0.4 \mathrm{~g}$ ) was taken in a conical flask, $1 \mathrm{~mL}$ phosphate buffer along with $1 \mathrm{~mL}$ supernatant from the culture was added and the mixture was shaken for $30 \mathrm{~min}$ at $37^{\circ} \mathrm{C}$. The reaction was terminated by the addition of $1 \mathrm{ml}$ of 1 (M) $\mathrm{HCl}$ and then the culture treated phospholipids were extracted with chloroform/methanol $(3: 1, \mathrm{v} / \mathrm{v})$ mixture. The extracted mixture was spotted on a TLC plate. First the plate was developed with Hexane and Ether (80:20, $\mathrm{v} / \mathrm{v})$ to separate the neutral lipids. The neutral lipids (DG, MG, and FFA) were visualized by iodine vapour and again extracted back from TLC plate with petroleum ether solvent $\left(40-60^{\circ} \mathrm{C}\right)$. The phospholipid fraction was again spotted on TLC plate and the plate was developed with chloroform/methanol/water (30:10:1 by vol). The spots were visualized by iodine vapour and extracted back by petroleum ether (40 $60^{\circ} \mathrm{C}$ ).

Gas Liquid Chromatogram gave the fatty acid composition of the products after preparing FAME of corresponding fatty acids (18).

Among the eight strains that were found to synthesize lipase, strain SB 3 shows the highest lipase activity of about $0.54 \mathrm{U} / \mathrm{ml}$ as determined by the cupric acetate method (Table 1) and gram staining and morphological test of that strain is given in (Table 2).

Table 1 Specific Activity of Bacterial Strains Isolated from Soyphospholipid Enriched Soil.

\begin{tabular}{|c|c|}
\hline Strain & $\begin{array}{c}\text { Specific activity of Lipase } \\
(\mathrm{U} / \mathrm{ml})\end{array}$ \\
\hline SB 1 & 0.12 \\
\hline SB 2 & 0.11 \\
\hline SB 3 & 0.54 \\
\hline SB 4 & 0.03 \\
\hline SB 5 & 0.51 \\
\hline SB 6 & 0.23 \\
\hline SB 7 & 0.33 \\
\hline SB 8 & 0.04 \\
\hline
\end{tabular}

(1U of enzyme activity $=1 \mu \mathrm{mol}$ of FFA produced $/ \mathrm{min}$ ) 
Table 2 Identification of Bacterial Strains.

\begin{tabular}{|c|c|}
\hline Characteristics & Strain SB 3 \\
\hline Gram & Negative \\
\hline Shape & Rod \\
\hline Number of flagella & $>1$ \\
\hline Fluorescent, diffusible pigments & + \\
\hline Non-diffusible no fluorescent pigments & - \\
\hline Poly- $\beta$-hydroxybutyrate accumulation & - \\
\hline Growth at $41^{\circ} \mathrm{C}$ & - \\
\hline Growth at $4^{\circ} \mathrm{C}$ & d \\
\hline Oxidase reaction & + \\
\hline Denitrification & - \\
\hline Gelatin hydrolysis & - \\
\hline Starch hydrolysis & - \\
\hline Utilisation of : Glucose & + \\
\hline Trehalose & - \\
\hline 2-Ketogluconate & + \\
\hline meso-inositol & - \\
\hline Geraniol & - \\
\hline 1-Valine & + \\
\hline$\beta$-Alanine & + \\
\hline 1-Arginine & + \\
\hline Nitrate used as a nitrogen source & + \\
\hline
\end{tabular}

Table 3 Comparison of Hydrolytic Activities of Lipases Obtained from SB 3 between Triacylglycerol and Phospholipid.

\begin{tabular}{ccc}
\hline Sample & $\begin{array}{c}\text { Hydrolysis of } \\
\text { triacylglycerol }\end{array}$ & $\begin{array}{c}\text { Hydrolysis of } \\
\text { phospholipid }\end{array}$ \\
\hline $\begin{array}{c}\text { with culture medium } \\
\text { containing no } \\
\text { phospholipid }\end{array}$ & $0.31 \pm 0.01$ & $0.49 \pm 0.11$ \\
\hline $\begin{array}{c}\text { with culture medium } \\
\text { containing } \\
\text { phospholipid }\end{array}$ & $0.54 \pm 0.09$ & $0.73 \pm 0.18$ \\
\hline
\end{tabular}

The higher hydrolytic activity of the strain towards phospholipid (Table 3) led to think about the presence of phospholipase enzyme which could be assessed by activities of the said enzyme on phospholipid itself. The effect of phospholipid in the culture medium in $1 \%$ level could also be understandable from the results shown in the Table 3.

When the phospholipid was hydrolysed with the enzyme isolated from the medium without any phospholipid, the fatty acid composition of the lysophospholipid obtained was almost similar to that obtained from the control system. This fact implies that the kind of lipase present in this enzyme preparation is either of random in nature or it is a mixture of lipase and phospholipase although have not been identified.

The kinds of enzymes collected from culture medium (of 72 and $96 \mathrm{~h}$ ) with and without phospholipid were reacted with deoiled phospholipid in presence of phosphate buffer at $\mathrm{pH} 7$ in order to ascertain the nature of hydrolyzed products. The resultant masses were extracted with chloroform and methanol, dried over sodium-sulphate and finally spotted on TLC plates. The plates were developed with Hexane: Diethyl ether $(60: 40, \mathrm{v} / \mathrm{v})$ and the spots were visualized by iodine vapour. In order to characterize the kinds of lipase obtained from no phospholipid medium, soyphospholipid was hydrolysed and the hydrolysis product were separated by TLC when two spots -- one of lysophospholipid and one of free fatty acid along with original phospholipid were visualized. Similarly kinds of lipases obtained from phospholipid containing medium when used to hydrolyse soyphospholipid, four spots - two of diglycerides, one of lysophospholipid and one of free fatty acid along with the original phospholipid were visualized by TLC separation. This observation led to think about the presence of different types of lipases in the enzyme preparation. Although not purified, but it appears that there may be two varieties of phospholipases viz. phospholipase A2 and phospholipase C and / $\mathrm{D}$ are present in the enzyme obtained from the phospholipid containing medium. The formation of diacylglyceride indicates the cleavage of phosphate bond from the phospholipid molecule. The fatty acid composition of two diacylglycerides produced from the isolated enzyme is shown in Table 4. The two different diacylglycerides, both of similar composition, was found in case of enzyme obtained from phospholipid containing medium and the fact can only be justified by the acyl migration of the fatty acid molecule through glycerol backbone.

The esterification activity units are based on measurement of initial rates, which may also vary with tem- 
Table 4 Fatty Acid Composition of the Diacylglycerides Produced from the Hydrolysis of Phospholipid by Enzymes Obtained from Phospholipid Containing medium.

\begin{tabular}{|c|c|c|c|c|c|}
\hline Sample & $\mathrm{C}_{16: 0}$ & $\mathrm{C}_{18: 1}$ & $\mathrm{C}_{18: 1}$ & $\mathrm{C}_{18: 2}$ & $\mathrm{C}_{18: 3}$ \\
\hline $\begin{array}{c}\text { Original } \\
\text { soyaphospholipid }\end{array}$ & 23.1 & 2.4 & 20.7 & 52.2 & 1.7 \\
\hline $\begin{array}{c}\text { Diacylglyceride obtained by } \\
\text { enzyme hydrolysis of } \\
\text { phospholipid (No. 1) }\end{array}$ & 31.6 & 3.6 & 25.6 & 36.1 & 0.9 \\
\hline $\begin{array}{c}\text { Diacylglyceride obtained by } \\
\text { enzyme hydrolysis of } \\
\text { phospholipid (No. 2) }\end{array}$ & 32.9 & 3.2 & 24.9 & 34.6 & 0.5 \\
\hline
\end{tabular}

Table 5 Comparison of the Esterification Activities between the Lipases Obtained from SB 3.

\begin{tabular}{|c|c|}
\hline Lipase & $\begin{array}{c}\text { Esterification activity in } 1 \mu \mathrm{mol} \text { of butyric } \\
\text { acid consumed per min per mg lipase }\end{array}$ \\
\hline $\begin{array}{c}\text { Lipase obtained from the no phospholipid } \\
\text { medium }\end{array}$ & $0.36 \pm 0.9$ \\
\hline $\begin{array}{c}\text { Lipase obtained from the medium } \\
\text { containing phospholipid }\end{array}$ & $0.67 \pm 0.11$ \\
\hline
\end{tabular}

perature and lipase source. The esterification of butanol with butyric acid was studied at 30, 40, 50 and $60^{\circ} \mathrm{C}$. At 30 and $40^{\circ} \mathrm{C}$, the extent of conversion was not satisfactory for accurate measurement of titre volumes. At $60^{\circ} \mathrm{C}$, the reaction did not exhibit any regularity in esterification behavior. Hence, only data obtained at $50^{\circ} \mathrm{C}$ is shown in Table 5. The results were highly reproducible. Although, the water activity of the reaction system was not determined. These results again prove the production of lipase enzymes with higher esterification activity in presence of phospholipid in the culture medium.

The production of lipase by Pseudomonas species is not uncommon. But simultaneous production of lipase and phospholipase by regulating the culture medium is prima facie new. This could be a valuable and potential finding to isolate phospholipase enzymes along with lipase from Pseudomonas species.

\section{References}

1. K. HATA, M. MATSUKARA, H. TANEDA and Y. FUJITA, Mill Scale Application of Enzymatic Pitch Control during Paper Production, Enzymes For Pulp And Paper Processing (T.W. JEFFRIES and L. VIIKARI, ed.), ACS Symposium Series, Washington DC, pp. 280-296 (1996).

2. Y. FUJITA, H. AWAJI, M. TANEDA, K. HATA, H. SHIMOTO, M. SHARYO, H. SAKAGUCHI and K. GIBSON, Recent Advances in Enzymatic Pitch Control, Tappi Journal, Vol. 75, 117-122 (1992).

3. K.D. MUKHERJEE, Lipase Catalysed Reactions for Modification of Fats and other Lipids, Biocatalysis, Vol. 3, 277-293 (1990).

4. M. DOOLITTLE and K. REUE, Lipase and Phospholipase Protocols, Lipase and Phospholipase Protocols, Humana Press Inc, USA, pp. 1-334 (1999).

5. E. ESPINOSA, S. SANCHEZ and A. FARRES, Nutritional Factors Affecting Lipase Production by Rhizopus delemar, Biotechnol Lett, Vol. 12, 204-209 (1990). 
6. K.A. TAN and C.O. GILL, Effect of Culture Conditions on Batch Growth of Pseudomonas fluorescens, Appl. Micrbiol Biotechnol, Vol. 23, 27-32 (1985).

7. M. CHARTRAIN, M. COLLEN, K. LORRAINE, S. SALMON, T. BRIX, B. BUCKLAND and R. GREASHAM, Enhancement of Lipase Production during Fed-batch Cultivation of Pseudomonas aeruginosa MB 5001, Ferment Bioeng, Vol. 76, 487 492 (1993)

8. A. SANCHEZ, P. FERRER, A. SERRANO, F. VALERO, C. SOLA, M. PERNAS, M.L. RUA, R. FERNANDEZLAFUENTE, J.M. GUISAN, R.M. DE LA CASA, J.V. SINISTERRA and J.M. SANCHEZ-MONTERO, A Controlled Fedbatch Cultivation for the Production of New Crude Lipase from Candida rugosa with Improved Properties in Fine Chemistry, $J$. Biotechnol, Vol. 69, 169-182 (1999).

9. Z.M. JUNKER, P. GAILLIOT, K. BYRNE and J. WILSON, Use of Soybean Oil and Ammonium Sulphate Addition to Optomise Secondary Metabolic Production, Biotechnol Bioeng, Vol. 60, 580-588 (1998).

10. S. BANDYOPADHYAY, D.K. BHATTACHARYYA, K. BANDYOPADHYAY and S. GHOSH, Characterisation of a Novel Lipase from Soil Isolate- Burkholderia cepacia SS-16, J. Oleo Sci., Vol. 49, 137-142 (2000).

11. F. PABAI, S. KERMASHA and A. MORIN, Use of Continuous
Culture to Screen for Lipase Producing Microorganisms and Interesterification of Butter Fat by Lipase, Can. J. Microbiol., Vol. 30, 446-459 (1996).

12. S.Y. LEE and J.S. RHEE, Production and Partial Purification of a Lipase from Pseudomonas putida 3SK, Enzyme and Microbial Technology, Vol. 15, 617-623 (1993).

13. T. IIZUMU, K. NAKAMURA and T. FUKASE, Purification and Characterisation of a Thermostable Lipase from Newly Isolated Pseudomonas sp. KWI-56, Agric. Biol. Chem., Vol. 54, 12531258 (1990).

14. S. BHATTACHARYYA, M. GHOSH and D.K. BHATTACHARYYA, Pseudomonas strains - as Sources of Biosurfactant, J. Oleo Sci., Vol. 52, 221-224 (2003).

15. G. HOLT, N.R. KRIEG, P.H.A. SNEAT, J.T. STALEY and S.T. WILLIAMS, Bergey's Manual of Determinative Bacteriology, Williams \& Wilkins, Baltimore, pp. 151-157 (1994).

16. D.Y. KWON and J.S. RHEE, A Simple and Rapid Colorimetric Method for Determination of Free Fatty Acid for Lipase Assay, J. Am. Oil Chem. Soc., Vol. 63, 89-94 (1986).

17. K.R. KIRAN, S. HARI KRISHNA, S. BABU, N.G. KARANTH and S. DIVAKAR, An Esterification Method for Determination of Lipase Activity, Biotechnol. Lett., Vol. 22, 1511-1514 (2000).

18. C. LITCHFIELD, Analysis of Triglycerides, Academic Press, New York, p.17 (1972). 